\title{
IMPLEMENTATION OF SOUND ABSORPTION MEASUREMENT BASED ON ISO AND ASTM STANDARDS IN BSN
}

\author{
Implementasi Pengukuran Sound Absorption Mengacu \\ pada Standar ISO dan ASTM di BSN
}

\author{
Bondan Dwisetyo', Dodi Rusjadi², Maharani Ratna Palupi ${ }^{3}$, Fajar Budi Utomo ${ }^{4}$, Chery Chaen \\ Putri $^{5}$, Ninuk Ragil Prasasti ${ }^{6}$, Denny Hermawanto ${ }^{7}$ \\ 1,2,3,4,5,6,7 Pusat Riset dan Pengembangan Sumber Daya Manusia, Badan Standardisasi Nasional \\ Komplek Puspiptek Gedung 435, Tangerang Selatan, Indonesia \\ E-mail: bondan@bsn.go.id
}

\begin{abstract}
The implementation of sound absorption measurement based on ISO and ASTM standard was carried out at National Standardization Agency of Indonesia (BSN). The aim of this work is to realize measurement of sound absorption, where the procedure is conducted based on ISO 354 and ASTM C423. In addition, the single number rating of the specimens also is determined based on ISO 11654, ASTM C423-17 and C423-99a. To measure the reverberation time inside a reverberation room, the interrupted noise method is used. Therefore, there are the significant differences between these standards related to the single number ratings of the test specimen. From the result, the significant deviation values is obtained for the three samples of perforation gypsum boards that provide the shape indicator information based on ISO standard that the values for the corresponding specimens are $0.75 \mathrm{~L}, 0.80 \mathrm{~L}$, and $0.65 \mathrm{~L}$ respectively. Meanwhile, either the current ASTM or the old version only inform the rating values without additional information that represented by SAA and NRC respectively that the values are 0.57 and 0.55 successively. Moreover, the result of this work will support the development of acoustic comparison coupler as a portable medium calibration that utilize the absorber as the supporting components.
\end{abstract}

Keywords : sound absorption coefficient, single number rating, ISO 354, ASTM C423, ISO 11654, Reverberation time

\begin{abstract}
Abstrak
Telah dilakukan implementasi pengukuran absorpsi bunyi mengacu pada standar ISO dan ASTM di Badan Standardisasi Nasional. (BSN). Tujuan dari penelitian ini yaitu merealisasikan pengukuran absorpsi bunyi dimana prosedur pengujiannya mengacu pada ISO 354 dan ASTM C423. Sebagai tambahan, nilai rating tunggal untuk beberapa sampel uji juga ditentukan yang mengacu pada ISO 11654, ASTM C423-17, dan C423-99a sebagai versi lama ASTM. Metode untuk mengukur waktu dengung di dalam ruang gema adalah metode interrupted noise method. Selanjutnya, terdapat beberapa perbedaan hasil yang signifikan pada standar yang digunakan terkait dengan penentuan nilai rating tunggal. Dari hasil pengujian, perbedaan siginikan ditemukan pada tiga sampel uji tipe perforation gypsum boards yang terdapat parameter shape indicator berdasarkan standar ISO yang nilainya masing-masing adalah 0,75L, 0,80L, dan 0,65L. Sedangkan untuk standar ASTM versi baru dan lama hanya menghasilkan nilai rating tanpa tambahan informasi yang diwakili oleh besaran SAA dan NRC yang masingmasing nilainya 0,57 dan 0,55. Lebih jauh lagi, hasil dari penelitian akan mendukung pengembangan acoustic comparison coupler sebagai media kalibrasi portabel yang memanfaatkan bahan penyerap sebagai komponen pendukung.
\end{abstract}

Kata kunci: koefisien absorpsi bunyi, nilai rating tunggal, ISO 354, ASTM C423, ISO 11654, waktu dengung

\section{INTRODUCTION}

The sound absorbing materials such as an acoustic ceiling and a sandwich panel, which have an important role to control noise within a room, have been used widely in Indonesia that shown a rapid growing in the infrastructure sectors in a recent years (Morgan, 2016). Because of the limitation of its fabrication, some of these materials have been imported from foreign countries by the manufacturers, designers and users, where the most of these specimens is ordered from European, Asia, and North American Countries. To ensure and verify the quality assurance of this product, therefore, it is necessary to be conducted a test serially that the procedure test is conform to the recognized standard. 
Currently, the national standard related to this materials test has not published yet in Indonesia. However, there are the international standard that commonly adopted either by institutions or manufacturers, and the following are: ISO and ASTM. The former commonly used for the European and some Asia nations product, whilst the later is adopted based on North America standard. Hereinafter, to comply the industrial necessity and market requisite related to the sound absorbing test of materials, SNSUBSN, one of the research institutions for acoustics and vibration in Indonesia, has the facilities and a capability to provide the measurement of sound absorption that refer to these aforementioned standards using the interrupted noise method for measuring the reverberation time and obtaining sound absorption coefficient, where the result of this test will be an indicator to determine the quality of an acoustic product. In this method, the reverberation time is measured inside a reverberation room without and with the specimens. After that, the sound absorption coefficient and the single number rating is determined to identify the quality of the samples.

Therefore, the purpose of this work is to realize measurement of sound absorption for the variance of sample test, where the procedure of the test is performed based on ISO 354 and ASTM C423. In addition, the single number rating of these products also is determined in this work based on ISO 11654, ASTM C423-17, and the old version of the second standard (ASTM C423-99a).

\section{BASIC THEORY}

In principle, either refer to ISO or ASTM, measurement of sound absorption of the material test is conducted by measuring the reverberation time inside a reverberation room (Jambrosic, Horvat, \& Domitrovic, 2008), that is commonly expressed as $\mathrm{RT}_{60}$ in seconds unit (s).

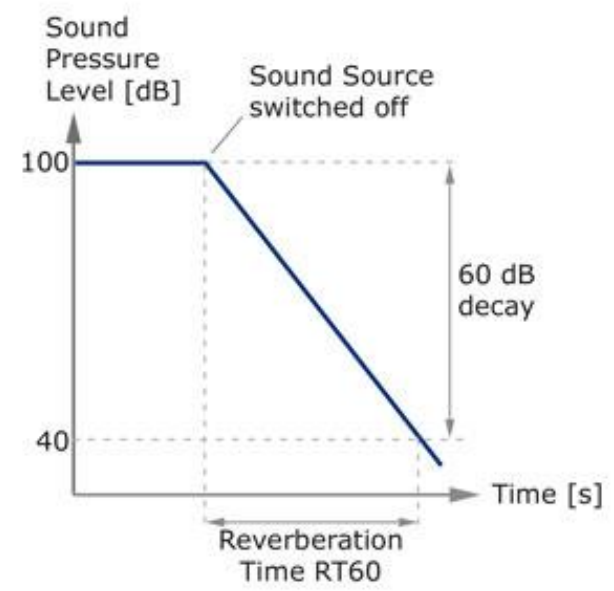

Figure 1. llustration of reverberation time

This quantity is defined as the time required for the sound source to reduce to a level of $60 \mathrm{~dB}$ when it is turned off inside a closed room (Prato, Casassa, \& Schiavi, 2016). Moreover, its illustration is shown in figure 1 , and it can be calculated using sabine formulation as follow:

$$
R T_{60}=0.16 \frac{V}{s_{g}}
$$

Where, $\mathrm{V}$ is volume of the enclosure, meanwhile $\mathrm{Se}$ is effective absorbing area and can be obtained using the equation as follows (Bistafa, 2014) :

$$
S_{e}=a_{1} S_{1}+a_{2} S_{2}+a_{a} S_{a}+\cdots
$$

Where, $\alpha$ is the absorption coefficient associated with a given area $\mathrm{S}$.

Practically, the most of building acoustics instruments has a capability to measure and calculate the reverberation time in an ordinary rooms at the same time (NTi Audio, 2016).

Furthermore, to determine the sound absorption coefficient, it is necessary to obtain the equivalent sound absorption area (in $\mathrm{m}^{2}$ ) inside the reverberation room without the sample test $\left(A_{1}\right)$, and with it $\left(A_{2}\right)$, and, therefore, these parameters can be calculated using the equation as follows (ISO 354, 2003) (ASTM C423, 2020):

$$
\begin{aligned}
& A_{1}=\frac{55 . a \mathrm{~V}}{C_{1} \cdot \operatorname{RT} 60_{1}}-4 V m_{1} \\
& A_{2}=\frac{55.3 \mathrm{~V}}{C_{2} \text { RTEO }}-4 V m_{2}
\end{aligned}
$$


Where, $c_{1}$ and $c_{2}$ is the speed of sound in air (in $\mathrm{m} / \mathrm{s}$ ) that is calculated after measuring a room temperature $\mathrm{t}$ (in ${ }^{\circ} \mathrm{C}$ ) in the two conditions using the equation as follows (ISO 354,2003 )

$$
\begin{aligned}
& c_{1}=\left(331+0,6 \cdot \frac{t_{1}}{{ }^{c}}\right) \\
& c_{2}=\left(331+0,6 \cdot \frac{t_{2}}{{ }_{c}}\right)
\end{aligned}
$$

From the equation (3) and (4), the measurement of sound absorption also is influenced by a sound attenuation in air that is represented by $\mathrm{m}_{1}$ and $\mathrm{m}_{2}$ respectively in the aforecited conditions, and it can be calculated using the equation : (ISO 354, 2003) (ASTM C423, 2020)

$$
\begin{aligned}
& m_{1}=\frac{\mathbb{E}_{1}}{10 \cdot \log e} \\
& m_{2}=\frac{\omega_{2}}{10 \cdot \log e}
\end{aligned}
$$

Where, $\alpha_{1}$ and $\alpha_{2}$ is the attenuation coefficient in air without and with the sample test respectively, where it is determined according to ISO 9613-1.

Subsequently, the equivalent sound absorption area $\left(A_{T}\right)$ of sample test (in $\mathrm{m}^{2}$ unit) can be determined using the equations as follows: (ISO 354, 2003) (ASTM C423, 2020) (Vercammen \& Lautenbach, 2014)

$$
A_{T}=A_{2}-A_{1}
$$

Hence, sound absorption coefficient (as) for every frequencies can be calculated using the formulation as follows : (ISO 354, 2003)

$$
\alpha_{s}=\frac{A_{T}}{s}
$$

\section{METHODOLOGY}

In this work, there are some steps to determine sound absorption coefficient based on ISO 354 and ASTM C423, and, therefore, the first step is measuring of environment parameters and reverberation time in a reverberation room without the sample. Basically, there are the two methods for measuring of $\mathrm{RT}_{60}$, and it is consists of the interrupted noise method and the integrating impulse response method (Passero \& Zannin, 2010). The former is conducted by using the sound source signal (pink noise or white noise), where it shall be long to produce a steady-state conditions of sound pressure level before it is switched off, where this method is used in this work (Rakerd et al., 2019). In order to obtain this conditions, the excitation time shall be a half of the estimate of the expected reverberation time.

For the impulse response method,, it is measured by using an impulse source directly such as MLS (maximum length sequence) signal, a pistol shot, balloon burst, spark gap or other sound source that produces an impulse with sufficient bandwidth and energy (Serafini, 2015)).

Hereinafter, the second step is applied by mounting the test sample inside the reverberation room, and after that, measuring $\mathrm{RT}_{60}$ with the sample test using the aforementioned method and the environmental parameters at the same time. In this stage, the similarity between both standards is identified at the requirement of frequency range, where they require the range frequency of $100 \mathrm{~Hz}-5000$ $\mathrm{Hz}$. Furthermore, the difference between these standards also is obtained, and it consists of the sample size, the requirement of room volumes, air gap used for testing, and the initialization of the decay slope calculation (Bischel, Roy, \& Greenslade, 2008). The first standard require a larger minimum room and minimum of sample size, where the values are $150 \mathrm{~m}^{3}$ and $10 \mathrm{~m}^{2}$ respectively, compare to the second standard are $125 \mathrm{~m}^{3}$ and $60 \mathrm{ft}^{2}(5.57 \mathrm{~m} 2)$ successively. Whilst, the second standard has a larger mounting air gap that its value is $400 \mathrm{~nm}$, meanwhile ISO has the requirement is $200 \mathrm{~nm}$ for Europe, and $300 \mathrm{~nm}$ for Japan that also used in this work (Bischel et al., 2008). After that, the sound absorption coefficient is determined by using the all above equations.

The final step of this work is to determine a single number ratings of the samples based on ISO 11654, ASTM C423, and old version of ASTM standard. In this step, method to calculate this parameter is quite different, and it is expressed as $\alpha_{w}$ (weighted sound absorption coefficient), and SAA (sound absorption average) for the two standards respectively. Additionally, the former is determined from the other parameter that is expressed as the practical sound absorption coefficients (api), where it is the function of frequency and based on measurements on one-third octave bands and 
calculated using equation (ISO, 2006) (BIAŁEK \& NOWICKA, 2018) :

$$
\alpha_{p i}=\frac{a_{i 1}+a_{i 2}+a_{i 3}}{a}
$$

Where, $\alpha_{i 1}, \alpha_{i 2}$ and $\alpha_{i 3}$ are the three of one-third octave sound absorption coefficients. After that, by refer to the reference values that shown in table 1, weighted sound absorption coefficient $\left(a_{w}\right)$ can be obtained by adjusting the reference curve that shown in Figure 2. (BIAŁEK \& NOWICKA, 2018)

Table 1. The reference values of sound absorption

\begin{tabular}{cc}
\hline $\begin{array}{c}\text { Frequency } \\
(\mathbf{H z})\end{array}$ & $\begin{array}{c}\text { Reference of sound } \\
\text { absorption } \\
\text { coefficients }\end{array}$ \\
\hline 250 & 0.80 \\
500 & 1.00 \\
1000 & 1.00 \\
2000 & 1.00 \\
4000 & 0.90 \\
\hline
\end{tabular}

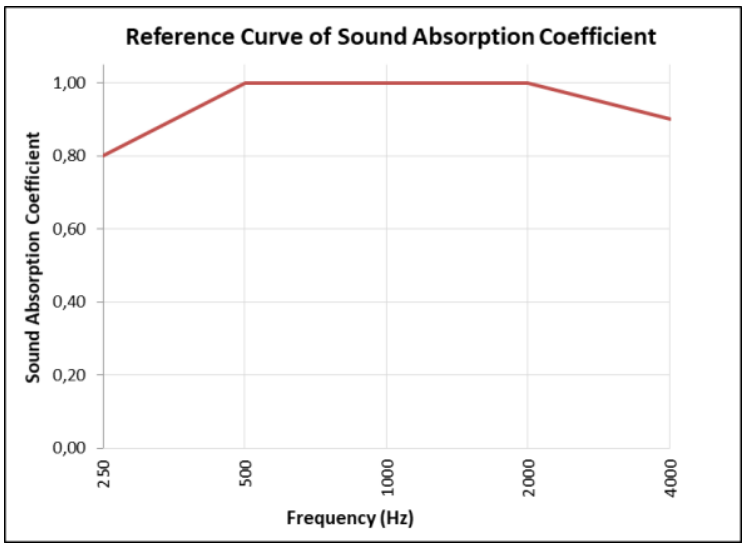

Figure.2. Reference curve based on ISO 11654

From this figure, the several steps are necessary to be applied. This curve is shifted in the steps of 0.05 through the ap values until the sum of unfavourable deviations is less or equal to 0.10 , where it can be achieved when the measured value of $a p$ is lower than the reference. Subsequently, the weighted sound absorption coefficient (aw) is obtained in this curve after adjusting the values at the frequency of $500 \mathrm{~Hz}$ (BIAŁEK \& NOWICKA, 2018).

In addition, there is additional information that should be determined if the practical sound absorption coefficient exceeds the reference value of curve at least by 0.25 . When this condition is achieved, a shape indicator parameter is necessary to be added to aw value, where the detail information of this indicator is shown in table 2 (BIAŁEK \& NOWICKA, 2018)

Table 2. the shape indicators of sound absorption

\begin{tabular}{cc}
\hline \hline Frequency (Hz) & Shape indicators \\
\hline 250 & $\mathrm{~L}($ Low) \\
500 or 1000 & $\mathrm{M}$ (Medium) \\
2000 or 4000 & $\mathrm{H}$ (High) \\
\hline \hline
\end{tabular}

Moreover, ISO 11654 also introduces sound absorption classes, which are categorizing the level of absorption performed by the given product that is shown in table 3 (BIAŁEK \& NOWICKA, 2018).

Table 3. Sound absorption classification of materials

\begin{tabular}{cc}
\hline $\begin{array}{c}\text { Sound } \\
\text { Absorption } \\
\text { Classes }\end{array}$ & $\begin{array}{c}\text { Weighted Sound } \\
\text { absorption Coefficient } \\
\left(\boldsymbol{\alpha}_{\mathbf{w}}\right)\end{array}$ \\
\hline $\mathrm{A}$ & $0.90,0.95,1.0$ \\
\hline $\mathrm{B}$ & $0.80,0.85$ \\
\hline $\mathrm{C}$ & $0.60,0.65,0.70,0.75$ \\
\hline $\mathrm{D}$ & $0.30,0.35,0.40,0.45$, \\
& $0.50,0.55$ \\
\hline $\mathrm{E}$ & $0.15,0.20,0.25$ \\
\hline F & $0.00,0.05,0.10$ \\
\hline
\end{tabular}

In contrast of the previous standard, there is no additional parameters for ASTM. The sound absorption average (SAA) is the average of the sound absorption coefficients that obtained from the twelve one-third octave bands from $200 \mathrm{~Hz}$ to $2500 \mathrm{~Hz}$ and rounded off to the nearest 0.01 (ASTM C423, 2020). This standard is only based on the single-number rating as a full description of sound absorption properties of the materials. It also mentions rating called Noise Reduction Coefficient (NRC), as the one used in the past and currently to be provided only for old ratings (BIAŁEK \& NOWICKA, 2018), where the difference to the newest standard is that NRC is the average of a material's absorption coefficients at 250, 500,1000, and $2000 \mathrm{~Hz}$, rounded to the closest 0.05 .

For the details, the apparatus measurement and facilities that used in this work are as follow:

1. White noise generator

2. Power amplifier

3. Dodecahedron loudspeaker

4. Diffuse field microphone

5. Modular precision sound analyzer 
6. Reverberation chamber

7. Sandwich panel

8. Test sample (Perforated and flatted gypsum board; Dimension (12 x $2400 \times 4800) \mathrm{mm}$ )

9. Test sample (Perforated and flatted sandwich panel; Dimension (12 x $2500 \times 4300) \mathrm{mm}$ )

10. Test sample (Rockwool $100 \mathrm{~kg} / \mathrm{m} 3$ and 120 $\mathrm{kg} / \mathrm{m3}$; Dimension (12 x $2400 \times 4800) \mathrm{mm}$ )

\section{EXPERIMENT}

\section{Measuring RT60 without the specimen test}

In this work, an experiment was set up using the aforementioned apparatus, and the first step is to measure the reverberation time without the sample test using interrupted noise method that is shown in Figure.3.
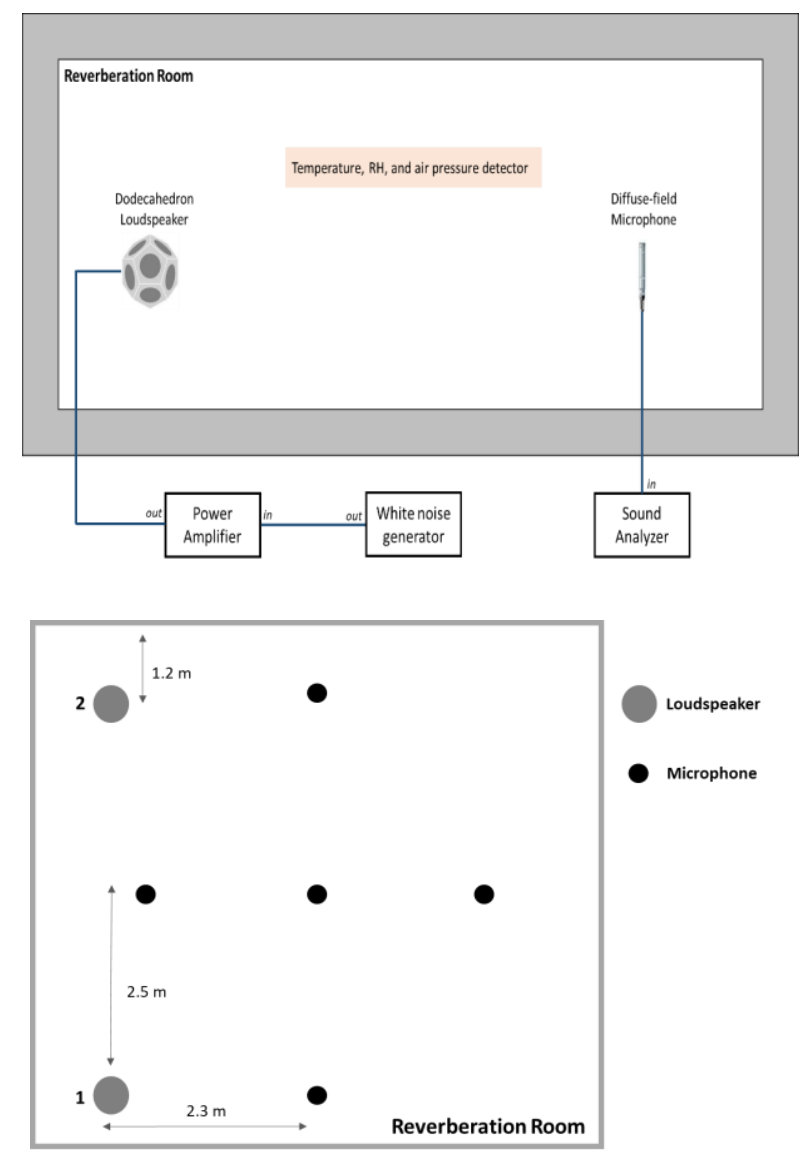

Figure3. Apparatus set up of reverberation time measurement without the sample

From this figure, a dodecahedron loudspeaker and a diffuse field microphone was placed inside the reverberation room, and, therefore, they were arranged so the distance between the both and the surfaces as the figure 3 (bottom). After that, the loudspeaker was connected to power amplifier and a white noise generator, meanwhile the microphone was plugged in to sound analyzer in a control room. Afterwards, by recording the environment parameters, and generating white noise from the generator, the reverberation time was indicated on the sound analyzer. For the other loudspeaker and microphone positions, the same steps was also applied.

\section{Measuring RT60 with the specimen test}

Whilst, the second step is conducted to measure the reverberation time with the test sample using the same method with the previous that is shown in Figure.4.
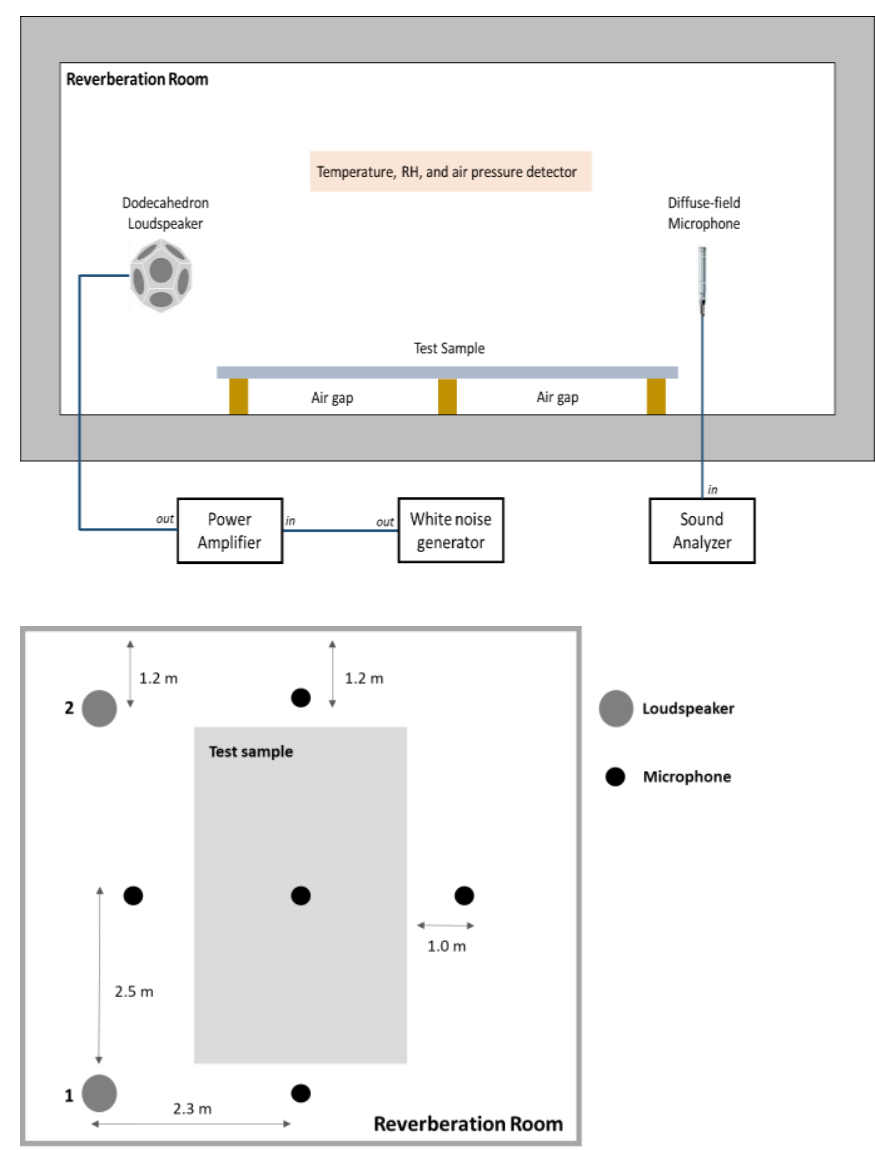

Figure.4. Measurement set up of reverberation with the sample

In this step, the test sample (gypsum boards) with the aforementioned dimensions was installed inside the reverberation room. It was 
placed on a wood frame with air gap about 300 $\mathrm{mm}$. After wards, the same step for measuring RT60 was applied. For the other materials, all the above steps also was conducted without installing of wood frame. After that, sound absorption coefficient was calculated using the equations above, and the single number rating was determined using the aforecited procedure of the two standards.

\section{RESULT AND DISCUSSION}

The result of the single number ratings determination of sound absorption coefficients for the variance of the sample test in this work are shown in Table 4.

Table 4. Result of sound absorption measurement

\begin{tabular}{ccccc}
\hline \hline No & Specimen Test & $\boldsymbol{\alpha}_{\mathrm{w}}$ & SAA & NRC \\
\hline 1 & $\begin{array}{c}\text { Perforated gypsum } \\
\text { board M1 }\end{array}$ & $0,75 \mathrm{~L}$ & 0,57 & 0,55 \\
\hline 2 & $\begin{array}{c}\text { Perforated gypsum } \\
\text { board M2 }\end{array}$ & $0,80 \mathrm{~L}$ & 0,58 & 0,60 \\
\hline 3 & $\begin{array}{c}\text { Perforated gypsum } \\
\text { board M8 }\end{array}$ & $0,65 \mathrm{~L}$ & 0,48 & 0,50 \\
\hline 4 & $\begin{array}{c}\text { Flatted gypsum } \\
\text { board }\end{array}$ & 0,20 & 0,14 & 0,15 \\
\hline 5 & $\begin{array}{c}\text { Perforated } \\
\text { sandwich panel } \\
\text { with rockwool 100 } \\
\mathrm{kg} / \mathrm{m}^{3}\end{array}$ & 1,00 & 0,96 & 0,95 \\
\hline 6 & $\begin{array}{c}\text { Flatted sandwich } \\
\text { panel with } \\
\text { rockwool 100 } \\
\mathrm{kg} / \mathrm{m}^{3}\end{array}$ & 0,50 & & \\
\hline 7 & $\begin{array}{c}\text { MG Rockwool 100 } \\
\mathrm{kg} / \mathrm{m}^{3}\end{array}$ & 1,00 & 0,96 & 0,95 \\
\hline 8 & $\begin{array}{c}\text { MG Rockwool 120 } \\
\mathrm{kg} / \mathrm{m}^{3}\end{array}$ & $0,95 \mathrm{H}$ & 0,92 & 0,95 \\
\hline \hline & & & \\
\hline
\end{tabular}

From this table, the difference values of the calculated single number ratings are vary for the specimens. For the perforated gypsum boards, ISO standard provides the shape indicator information of the three samples that the values for the corresponding specimens are $0,75 \mathrm{H}$, $0,80 \mathrm{H}$, and $0,65 \mathrm{H}$ respectively, where it means that at the frequency of $250 \mathrm{~Hz}$, the practical sound absorption coefficient exceeds the adjusted reference value of curve by 0,25 as 3 shown in figure 5 . In this figure, the three perforated gypsum board are shown in the red, purple, and green line successively, where the solid lines represent the reference values of sound absorption coefficient, whilst the materials test values is illustrated by the dotted lines.

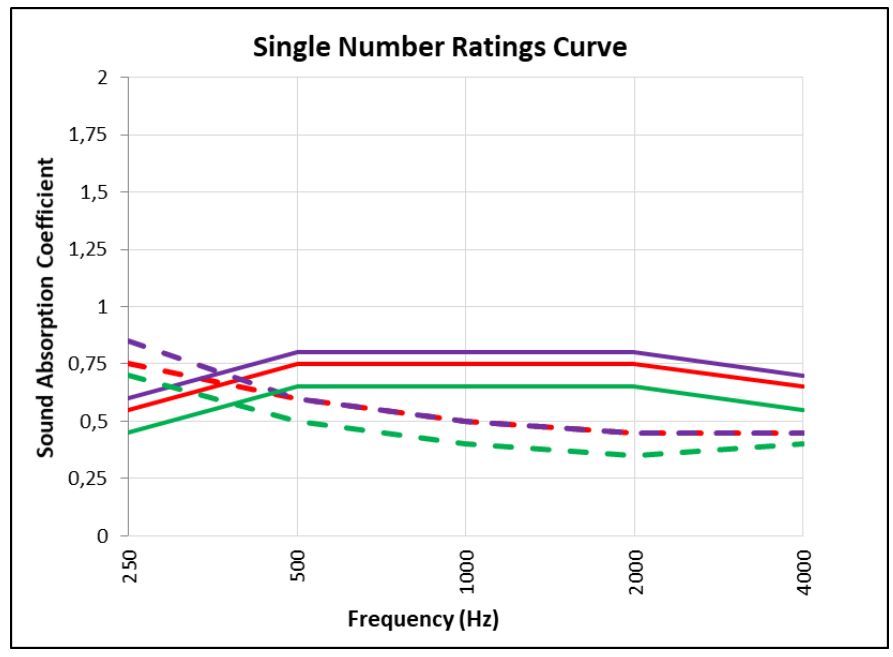

Figure 5. The single number rating curves of the perforated gypsum board

Passingly, either the current ASTM or its old version only inform the rating values without the additional information that represented by 0,57 for SAA, and 0,55 belongs to NRC. Moreover, the deviation values of this rating within the ASTM standards is relative slight, where it has the deviation values is about 0,02 . In contrast of the American standard, ISO provides the larger rating values, and its difference to ASTM is large relatively, where the values of these sample has the deviations about 0,15 to 0,25 . Subsequently, the flatted gypsum has no supplementary information among these standards, and it is found that the single number ratings value for ISO is 0,20 , meanwhile for the ASTM are 0,14 for the newest version, and 0,15 for the other. Afterwards, the deviation values that obtained between the standards is not significant, where it is found about 0,05 to 0,06 .

Therefore, the sandwich panels also has a similarity to the previous samples, where it has only the single number rating values for the two specimens, and it is found that its values are 1,00 and 0,50 respectively for European standards, 0,96 and 0,31 serially for ASTM, 0,95 and 0,30 for its old standard. However, it is found that there are a difference of the rating values based on the standards. The perforated compound tend to has an equal values of the single number rating among these standards, 32 anwhile the flatted material provides the iation value is about 0.20 to 0.21 . 
For the last specimens test, it has a resemblance with the perforated gypsum boards that provide the extra information of the rating value for ISO standard. Hereinafter, for the larger density, the single number rating values is found that its value is about $0,95 \mathrm{H}$, where it means that the practical sound absorption coefficient has a larger value than the reference value of curve at the corresponding frequencies as shown in figure 6 . In this figure, the two boards are shown in the red, and purple successively, where the solid lines represent the reference values of sound absorption coefficient, whilst the materials test values is illustrated by the dotted lines. Meanwhile for the other rockwool test, the single number rating values is found, where it has no shape indicator, and its value is 1,00 . Therefore, the two of ASTM standards have the similar of single number rating values that they are 0,96 and 0,95 respectively.

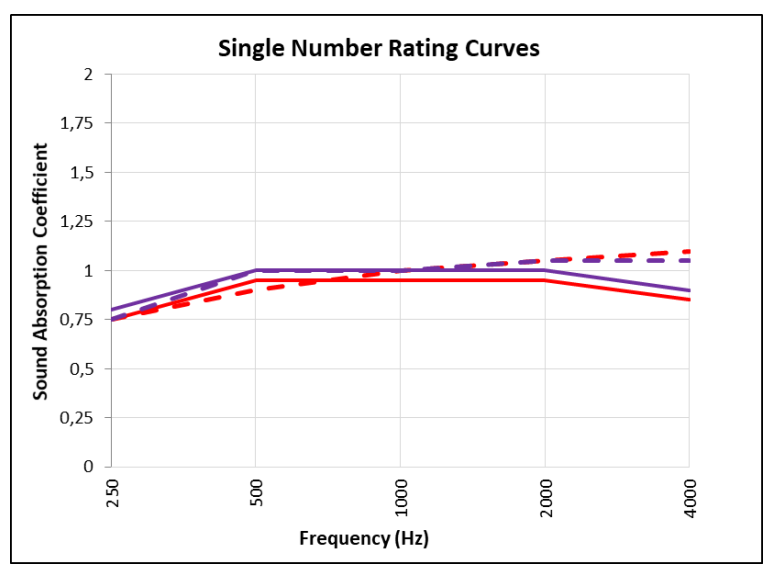

Figure.6. The single number rating curves of the perforated gypsum board

\section{CONCLUSION}

In this work, the implementation of sound absorption measurement for the variance of test sample based on ISO 354 and ASTM C423 was carried out at The Deputy of National Measurement Standard BSN by Research Group for Acoustics and Vibration. In addition, the single number rating of these products also is determined in this work based on ISO 11654, ASTM C423 and the old version of the second standard (ASTM).

There are the significant deviation between ISO and ASTM standard related to the single number ratings of the aforecited specimen test. From the result, the significant difference values is obtained for the perforated gypsum boards that provide the shape indicator information of the three samples based on ISO standard that the values for the corresponding specimens are $0,75 \mathrm{~L} 0,80 \mathrm{~L}$, and $0,65 \mathrm{~L}$ respectively. Meanwhile, either the current ASTM or the old version only inform the rating values without additional information that represented by SAA and NRC respectively that the values are 0,57 and 0,55 successively.

Moreover, this experiment is necessary to be continued strongly using the integrating impilse respons method to conduct the reverberation time measurement, and additional of the specimen test to provide an reliable result. Therefore, a comparison of the result can be studied and analized further.

\section{ACKNOWLEDGEMENT}

The authors acknowledge the support of Head of Center for Research and Human Resources Development (PUSRISBANG), National Standardization Agency of Indonesia (BSN) through the scheme of the institution internal research in the current year.

In addition, the authors also thank to PT Aplus Pacific, PT Jayaboard, PT FIRM, and PT Nichias Rockwool Indonesia that provide the approving for using of the measurement data.

\section{REFERENCES}

ASTM C423. (2020). Standard Test Method for Sound Absorption and Sound Absorption Coefficients by the Reverberation Room Method 1. https://doi.org/10.1520/C042317.2

BIAŁEK, J., \& NOWICKA, E. (2018). Comparison of sound absorption ratings calculated according to ISO and ASTM standards, (September 2016). Retrieved from https://www.researchgate.net/publication/32 2570077\%0AComparison

Bischel, M. S., Roy, K. P., \& Greenslade, J. V. (2008). Comparison of ASTM and ISO sound absorption test methods. Proceedings - European Conference on Noise Control, 1669-1674. https://doi.org/10.1121/1.2933311

Bistafa, S. R. (2014). Reverberation time and maximum background-noise level for classrooms from a comparative study of speech intelligibility metrics NRC Publications Archive ( NPArC) Archives 
des publications du CNRC ( NPArC) A Comparative Study of Speech Intelligibility $\mathrm{Me}$, (March 2000). https://doi.org/10.1121/1.428268

ISO, 11654. (2006). INTERNATIONAL buildings - Rating of sound absorption, 1997(1997)

ISO 354. (2003). Acoustics - Measurement of sound absorption in a reverberation room.

Jambrosic, K., Horvat, M., \& Domitrovic, H. (2008). Reverberation time measuring methods. Proceedings - European Conference on Noise Control, (June), 4503-4508.

https://doi.org/10.1121/1.2934829

Morgan, S. M. (2016). Selection of Noise Barrier Material, https://doi.org/10.3141/1756-07

(July).

NTi Audio. (2016). Reverberation Time RT60, 112. Retrieved from http://www.ntiaudio.com/en/functions/reverberation-timert60.aspx

Passero, C. R. M., \& Zannin, P. H. T. (2010). Statistical comparison of reverberation times measured by the integrated impulse response and interrupted noise methods, computationally simulated with ODEON software, and calculated by Sabine, Eyring and Arau-Puchades' formulas. Applied Acoustics, 71(12), 1204-1210. https://doi.org/10.1016/j.apacoust.2010.07. 003
Prato, A., Casassa, F., \& Schiavi, A. (2016). Reverberation time measurements in nondiffuse acoustic field by the modal reverberation time. Applied Acoustics, 110(July 2018), 160-169. https://doi.org/10.1016/j.apacoust.2016.03. 041

Rakerd, B., Hunter, E. J., Berardi, M., Bottalico, P., Lansing, E., \& Science, H. (2019). with Examples, (517). https://doi.org/10.1044/persp3.SIG19.8.Ass essing

Serafini, M. (2015). a Hybrid Method for Impulse Response Measurements With Synthesized Musical Tones and Masked-Mls Stimuli a Hybrid Method for Impulse Response Measurements With Synthesized Musical Tones and Masked-Mls Stimuli.

Vercammen, M., \& Lautenbach, M. (2014). Improvement of the measurement of the sound absorption using the reverberation chamber method. The Journal of the Acoustical Society of America, 135(4), 2380-2380.

https://doi.org/10.1121/1.4877860 